\title{
Electrodeposited Cobalt-Iron Alloy Thin-Film for Potentiometric Hydrogen Phosphate-Ion Sensor
}

\author{
Toru Kidosaki, Satoko Takase, Youichi Shimizu* \\ Department of Applied Chemistry, Graduate School of Engineering, Kyushu Institute of Technology, Fukuoka, Japan \\ Email: ${ }^{*}$ shims@tobata.isc.kyutech.ac.jp
}

Received March 27, 2012; revised April 25, 2012; accepted May 29, 2012

\begin{abstract}
A cobalt-iron alloy thin-film electrode-based electrochemical hydrogen-phosphate-ion sensor was prepared by electrodepositing on an Au-coated $\mathrm{Al}_{2} \mathrm{O}_{3}$ substrate from an aqueous solution of metal-salts. The use of a cobalt-iron alloy electrode greatly improved the hydrogen-ion sensor response performance, i.e., the sensor worked stably for more than 7 weeks and showed a quick response time of several seconds. Among the cobalt and iron alloy systems tested, the electrodeposited $\mathrm{Co}_{58} \mathrm{Fe}_{42}$ thin-film electrode showed the best EMF response characteristics, i.e., the sensor exhibited a linear potentiometric response to hydrogen-phosphate ion at the concentration range between $1.0 \times 10^{-5}$ and $1.0 \times 10^{-2} \mathrm{M}$ with the slope of $-43 \mathrm{mV} /$ decade at $\mathrm{pH} 5.0$ and at $30^{\circ} \mathrm{C}$. A sensing mechanism of the Co-based potentiometric hydrogen-phosphate ion sensor was proposed on the basis of results of instrumental analysis.
\end{abstract}

Keywords: Hydrogen-Phosphate Ion Sensor; Cobalt-Iron Alloy; Thin-Film Electrode; Electrodeposition

\section{Introduction}

Phosphate is an important element that is used widely for various industrial applications such as metal plating and food processing. However, phosphate has been a major factor of eutrophication in closed natural systems such as lakes, rivers and bays. Thus, determination of the exact amounts of (hydrogen)-phosphate ions in water systems has become important for environmental analysis. The conventional spectrophotometric method that is widely used has a high level of accuracy but is not suitable for on-site monitoring because of complex procedures including formation of a phosphate-molybdate complex. Considerable efforts have been made to develop highperformance ion sensors for monitoring hydrogenphosphate-ion concentration, such as ion-selective electrodes [1-7], bio-related systems [8], hydroxyapatite-based electrodes [9], electrochromic devices [10,11], and amperometric devices $[12,13]$. Among these phosphate-ion sensors, ISE (ion-selective electrode)-based sensors using polymer membranes, with calixarene or molybdenumacetylacetonate $[14,15]$ are effective but still have problems in selectivity and/or stability. Xiao et al. reported that a cobalt metal electrode exhibited good potentiometric response and selectivity to dihydrogen-phosphate ion $\left(\mathrm{H}_{2} \mathrm{PO}_{4}^{-}\right)$among common anions in an acidic medium [4]. Meruva and Meyerhoff showed that a Co-wire electrode responded well to hydrogen-phosphate $\left(\mathrm{H}_{2} \mathrm{PO}_{4}^{-}\right)$

${ }^{*}$ Corresponding author. and phosphate $\left(\mathrm{PO}_{4}^{3-}\right)$ ions in different $\mathrm{pH}$ solutions [3]. It was revealed that a Co-wire-based hydrogen-phosphate ion sensor had a low concentration detection limit and a broad detection range [16-18]. A disposable on-chip hydrogen-phosphate ion sensor with planar cobalt microelectrodes on a polymer substrate has also been reported [19]. These Co-based sensors are particularly attractive as hydrogen-phosphate ion sensors; however, a Co metal-based sensor seems to still lack stability for practical use. The sensing mechanism of the Co-based potentiometric sensor has still not been clarified.

In this study, it was found that the use of a cobalt-iron metal-alloy electrode drastically improved not only the stability of the sensor device but also its sensitivity to hydrogen-phosphate ion. A sensing mechanism of the Co-based potentiometric hydrogen-phosphate ion sensor was also proposed on the basis of characterization of the materials.

\section{Experimental}

A commercial alumina $\left(\mathrm{Al}_{2} \mathrm{O}_{3}\right)$ sintered plate (SSA-T, 10 $\times 20 \times 0.5^{\mathrm{t}}: \mathrm{mm}$, Nikkato Ltd., Japan) was used as a substrate for the sensor devices. An Au coating $(10 \times 10$ $\mathrm{mm}^{2}$ ) on $\mathrm{Al}_{2} \mathrm{O}_{3}$ as an electrode for electrodeposition was prepared by painting with Au-paste (TKK Ltd., Japan) and heating at $900^{\circ} \mathrm{C}$. The prepared Au-attached alumina substrate and Pt plate $\left(10 \times 20 \times 1^{\mathrm{t}}: \mathrm{mm}\right)$ were used as cathode and anode electrodes, respectively, for electrodepositing. The distance between the two electrodes was 
fixed at $10 \mathrm{~mm}$.

The aqueous solution $(250 \mathrm{~mL})$ used for Co-only electrodeposition consisted of $1.1 \mathrm{~mol} / \mathrm{L} \mathrm{CoSO}{ }_{4} \cdot 7 \mathrm{H}_{2} \mathrm{O}, 0.022$ $\mathrm{mol} / \mathrm{L}_{3} \mathrm{BO}_{3}$, and $0.051 \mathrm{~mol} / \mathrm{L} \mathrm{NaCl}$ with $\mathrm{pH}$ of 5.04 . For $\mathrm{Co}-\mathrm{Fe}$ alloy electrodeposition, metal sulfate solutions $(\mathrm{A}, \mathrm{B}$, and $\mathrm{C}$ ) were firstly prepared as follows. Concentration ratios $\left[\mathrm{CoSO}_{4} \cdot 7 \mathrm{H}_{2} \mathrm{O}\right] \quad(\mathrm{mol} / \mathrm{L}) /\left[\mathrm{FeSO}_{4} \cdot 7 \mathrm{H}_{2} \mathrm{O}\right]$ $(\mathrm{mol} / \mathrm{L})$ in solutions $\mathrm{A}, \mathrm{B}$, and $\mathrm{C}$ were $0.090 / 0.270$, $0.200 / 0.166$, and $0.267 / 0.089$, respectively. Metal sulfate solution $\left(\mathrm{A}, \mathrm{B}\right.$, or $\mathrm{C}$ ) consisting of $0.041 \mathrm{~mol} / \mathrm{L} \mathrm{H}_{3} \mathrm{BO}_{3}$ and $0.51 \mathrm{~mol} / \mathrm{L} \mathrm{NaCl}$ with $\mathrm{pH}$ of 2.00 and total volume of $250 \mathrm{~mL}$ was finally prepared for Co-Fe alloy electrodeposition. All metal thin-film electrodes were electrochemically deposited at a constant current of $100 \mathrm{~mA} / \mathrm{cm}^{2}$ for $180 \mathrm{~s}$ at room temperature.

The deposited metal films were characterized by means of X-ray diffractometry (XRD, JDX-3500K JEOL), X-ray photoelectron spectroscopy (XPS, JPS-90SX JEOL), and FT-IR spectroscopy (Magna760, Nicolet). Thicknesses of the metal-alloy electrodes were determined by scanning electron microscopy (FE-SEM, ERA8800, ELIONIX). Elemental composition of the prepared metal electrodes was determined by using an X-ray micro-analysis system (EDX, Genesis XM2 EDAX).

An electrochemical cell assembly (Metal electrode| sample solution $\left.\| \mathrm{Ag} / \mathrm{AgCl}, \mathrm{KCl}_{\text {(sat.) }}\right)$ was used for potentiometric sensor measurements. Electromotive force (EMF) was measured by using an electrometer (R8240, Advantest Ltd.) in $0.1 \mathrm{M}$ phthalate buffer solution with various anion concentrations between $1.0 \times 10^{-6}$ and 1.0 $\times 10^{-2} \mathrm{M}$ at $30^{\circ} \mathrm{C}$ using their potassium salts.

\section{Results and Discussion}

\subsection{Structure of the Metal Film Electrode}

X-ray microanalysis of Co-Fe alloy electrodeposited films prepared from three different solutions (A, B, and C) revealed that the element compositions of $\mathrm{Co}$ and $\mathrm{Fe}$ in the alloys were at $\mathrm{Co}_{36} \mathrm{Fe}_{64}, \mathrm{Co}_{58} \mathrm{Fe}_{42}$ and $\mathrm{Co}_{75} \mathrm{Fe}_{25}$, respectively, depending on the Co concentration in the electrolyte bath.

Figure 1 shows XRD patterns of the as-prepared Co and $\mathrm{Co}_{58} \mathrm{Fe}_{42}$ thin-film electrodes. Peaks observed in Figure 1(a) include an fcc phase of Co (JCPDS: \#05-0727) and impurity phases of $(\beta$-)CoOOH (\#14-0673) [20] and $\mathrm{CoSO}_{4}(\# 11-125)$. They should be come from electrodeposition and the electrolyte solution used, respectively. As shown in Figure 1 (b), the $\mathrm{Co}_{58} \mathrm{Fe}_{42}$ metal alloy consists of a bcc phase of $\mathrm{Co}_{50} \mathrm{Fe}_{50}$ (\#44-1433) as well as a trace amount of $(\gamma-) \mathrm{FeOOH}(\# 8-98)$. Other small peaks at 15 and 19 degrees $\left(\mathrm{CuK}_{\alpha 1}\right)$ are assigned to $\mathrm{CoCl}_{2}$ (\#15$381)$ and $\mathrm{Co}(\mathrm{OH})_{2}(\# 30-443)$, respectively. Since most of the impurity phases easily dissolve in the aqueous solution during sensing, these metal thin-films mainly consist of metal-based electrodes.

Figure 2 shows SEM images of cross-sectional views of the $\mathrm{Co}$ and $\mathrm{Co}_{58} \mathrm{Fe}_{42}$ thin-film electrodes. They are adhered tightly onto the Au layer. The thicknesses of the $\mathrm{Co}$ and $\mathrm{Co}_{58} \mathrm{Fe}_{42}$ thin-film electrodes were about 0.8 and $1.0 \mu \mathrm{m}$, respectively.

\subsection{Sensing Performance of the Metal Film Electrode}

The Co metal thin-film electrode showed relatively good EMF response characteristic to $\mathrm{H}_{2} \mathrm{PO}_{4}^{-}$, as has already been reported by many researchers [4,16-19]. The prepared Co-only sensor responded well to $\mathrm{H}_{2} \mathrm{PO}_{4}^{-}$in the concentration range of $1.0 \times 10^{-4}$ to $1.0 \times 10^{-2} \mathrm{M}$, as shown in Figure 3(a). The 90\% response time of the Co metal electrode to $1.0 \mathrm{mM} \mathrm{H}_{2} \mathrm{PO}_{4}^{-}$was about $32 \mathrm{~s}$. It

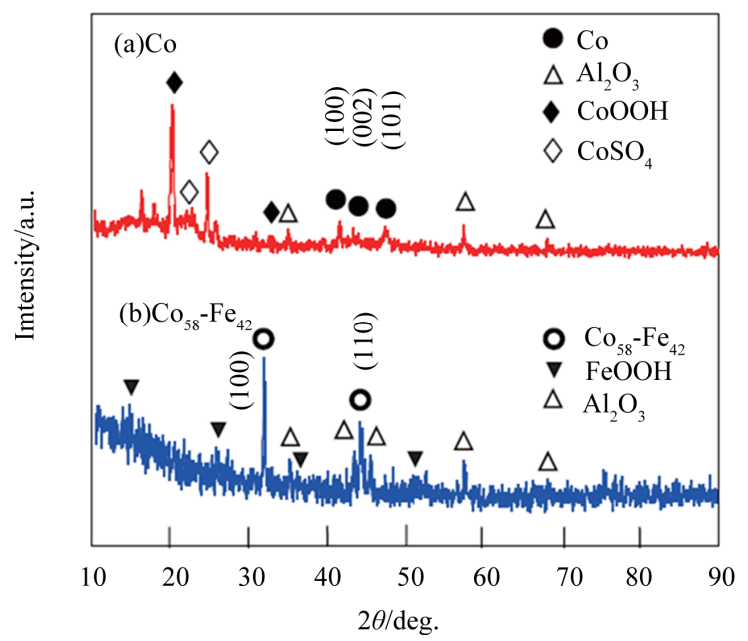

Figure 1. XRD patterns of (a) $\mathrm{Co}$ and (b) $\mathrm{Co}_{58} \mathrm{Fe}_{42}$ thin-films as-prepared by electroplating.

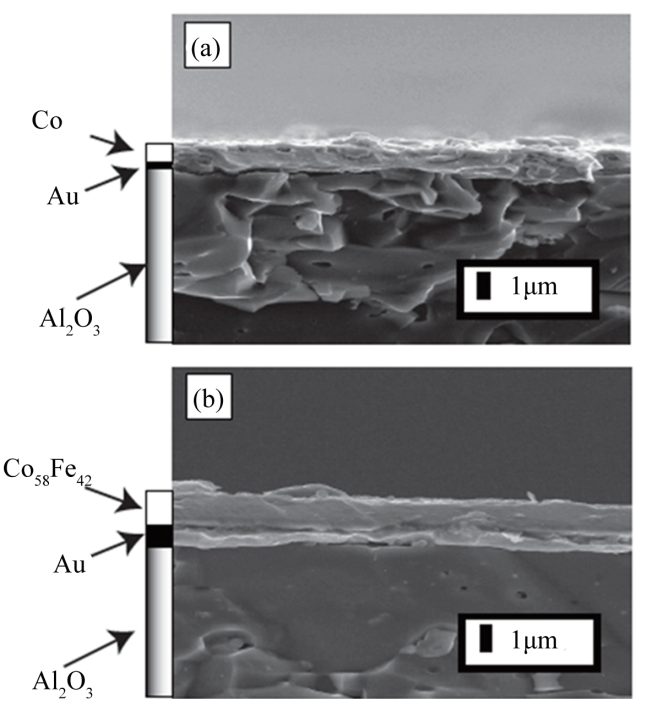

Figure 2. SEM images of cross-sectional views of (a) Co and (b) $\mathrm{Co}_{58} \mathrm{Fe}_{42}$ thin-film electrodes. 
was also found that the use of a Co-Fe alloy system electrode improved the response performance. As shown in Figure 3(b), the $\mathrm{Co}_{58} \mathrm{Fe}_{42}$ alloy thin-film electrode sensor responded more clearly to $\mathrm{H}_{2} \mathrm{PO}_{4}^{-}$in the concentration range of $1.0 \times 10^{-5}$ to $1.0 \times 10^{-2} \mathrm{M}$, better than that of the Co-only electrode. The $90 \%$ response time of the $\mathrm{Co}_{58} \mathrm{Fe}_{42}$

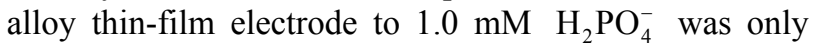
$13 \mathrm{~s}$. It was also found that the use of a Co-Fe alloy system electrode drastically improved the stability of the sensor. Although the Co-only thin-film electrode showed good EMF response to $\mathrm{H}_{2} \mathrm{PO}_{4}^{-}$at the concentration range of $1.0 \times 10^{-4}$ to $1.0 \times 10^{-2} \mathrm{M}$, the response gradually shifted within 2 weeks as shown in Figure 4(a). On the other hand, it was revealed that the $\mathrm{Co}_{58} \mathrm{Fe}_{42}$ alloy thin-film electrode showed stable EMF response to $\mathrm{H}_{2} \mathrm{PO}_{4}^{-}$in the concentration range of $1.0 \times 10^{-5} \mathrm{M}$ to 1.0 $\times 10^{-2} \mathrm{M}$ for more than 7 weeks as shown in Figure 4(b). Hydrogen-phosphate ion response characteristics of the $\mathrm{Co}-\mathrm{Fe}$ thin film device, as a function of metal composi-

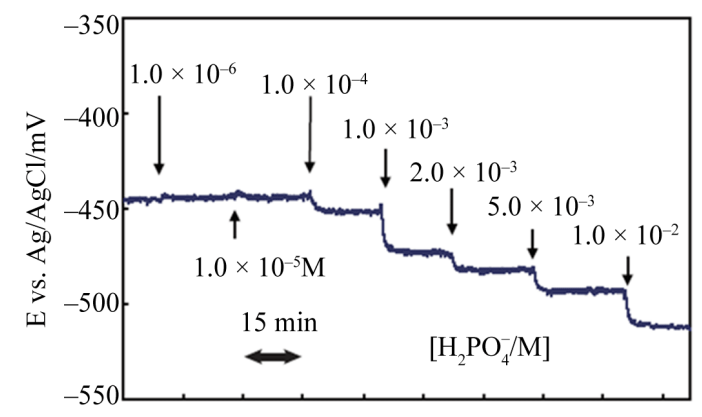

(a)

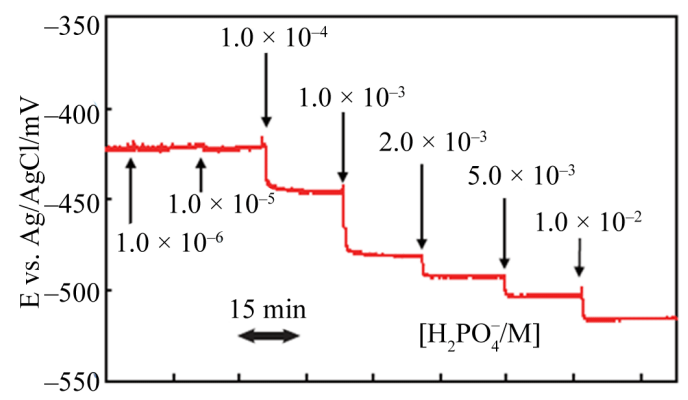

(b)

Figure 3. EMF response transient of the $\mathrm{Co}_{58} \mathrm{Fe}_{42}$ thin-film electrode to hydrogen-phosphate ion at $30^{\circ} \mathrm{C}$. tion ratio are summarized in Table $\mathbf{1}$. It was shown out that the sensitivity and stability to $\mathrm{H}_{2} \mathrm{PO}_{4}^{-}$depends on the composition of the electrode materials. The sensitivity here was expressed in terms of slope in the EMF change (mV/decade), as well as the $90 \%$ response time from $1 \mathrm{mM}$ to $3 \mathrm{mM} \mathrm{H} \mathrm{H}_{2} \mathrm{PO}_{4}^{-}$. In the Co-Fe system, the slope increased with increasing Fe content in Co-Fe alloy up to 42 at $\%$ Fe. Lower concentration limit was obtained using triple the background noise. Faster response time and long-term stability were also observed with increase in $\mathrm{Fe}$ content in the Co-Fe alloy up to 42 at $\% \mathrm{Fe}$. On the other hand the sensor performances (slope, response time and stability) of the Co-Fe system decreased at higher $\mathrm{Fe}$ content of 64 at $\% \mathrm{Fe}\left(\mathrm{Co}_{36} \mathrm{Fe}_{64}\right)$ in the Co-Fe alloy. Among the Co-Fe systems tested, the $\mathrm{Co}_{58} \mathrm{Fe}_{42}$ alloy thin-

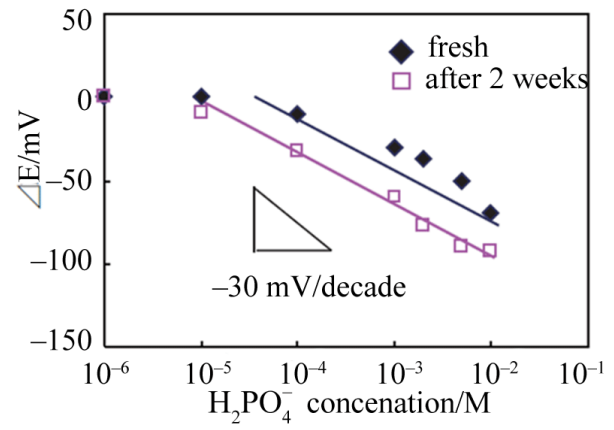

(a)

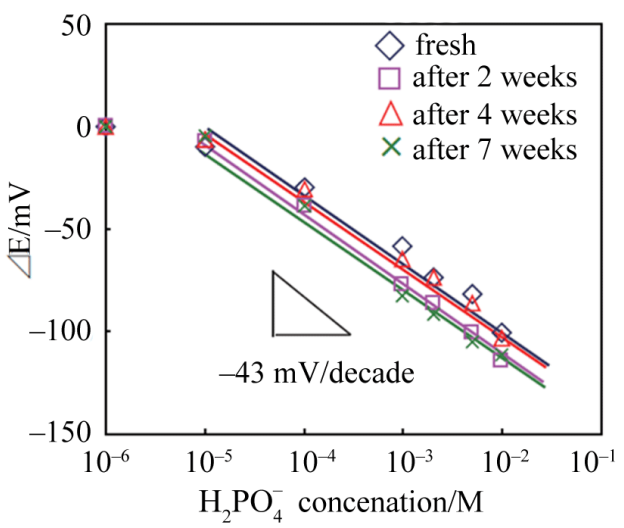

(b)

Figure 4. Stability of (a) $\mathrm{Co}$ and (b) $\mathrm{Co}_{58} \mathrm{Fe}_{42}$ thin-film sensors to hydrogen-phosphate ion at $30^{\circ} \mathrm{C}$.

Table 1. Hydrogen-phosphate ion sensing characteristics of the Co-Fe thin-film device with various elemental ratios.

\begin{tabular}{cccccc}
\hline Metal thin-film & Lower detection limit ${ }^{\mathrm{a}}[\mathrm{M}]$ & Slope $[\mathrm{mV} / \mathrm{dec}]$ & Response time $^{\mathrm{b}}[\mathrm{s}]$ & Stability [weeks] & Sensing performance \\
\hline $\mathrm{Co}$ & $1.0 \times 10^{-4}$ & -30 & 32 & 3 & Good \\
$\mathrm{Co}_{75} \mathrm{Fe}_{25}$ & $1.0 \times 10^{-4}$ & -38 & 30 & 4 & Good \\
$\mathrm{Co}_{58} \mathrm{Fe}_{42}$ & $1.0 \times 10^{-5}$ & -43 & 13 & 7 & Very good \\
$\mathrm{Co}_{36} \mathrm{Fe}_{64}$ & $1.0 \times 10^{-3}$ & -16 & 46 & 1 & Poor \\
$\mathrm{Fe}$ & No response & - & - & - & Poor \\
\hline
\end{tabular}

${ }^{\mathrm{a}}$ concentration range giving triple signal from the background noise; ${ }^{\mathrm{b}}$ from 0.1 to $1.0 \mathrm{mM} \mathrm{H}_{2} \mathrm{PO}_{4}^{-}$. 
film electrode showed the best EMF response characteristic to $\mathrm{H}_{2} \mathrm{PO}_{4}^{-}$.

At this point, the sensing mechanism is a hypothesis. The tendency was similar for the magnetic relation for a $\mathrm{Co} / \mathrm{Fe}$ alloy system [21]. This should be come from the electric inter-molecule interaction between the $\mathrm{Co} / \mathrm{Fe}$ electrode and the hydrogen-phosphate ion which has 3 electrons in a $3 p$ orbital in the P-atom. This might be due to the high hydrogen-phosphate ion adsorption when $\mathrm{Co} / \mathrm{Fe}$ alloys were introduced, and magnetic properties might therefore be important for the phosphate-ion sensing.

Phosphate-ion response characteristics of the $\mathrm{Co}_{58} \mathrm{Fe}_{42}$ thin-film electrode at various $\mathrm{pH}$ values are shown in Figure 5. Between $\mathrm{pH} 5.1$ and 12.2, the best EMF response was observed at $\mathrm{pH} 5.1$, indicating that this sensor easily responds to $\mathrm{H}_{2} \mathrm{PO}_{4}^{-}$among the phosphate-based anions $\left(\mathrm{PO}_{4}^{3-}, \mathrm{H}_{2} \mathrm{PO}_{4}^{2-}, \mathrm{H}_{2} \mathrm{PO}_{4}^{-}\right)$. Figure 6 shows the selectivity of the $\mathrm{Co}_{58} \mathrm{Fe}_{42}$ thin-film electrode to various anions $\left(\mathrm{HCO}_{3}^{-}, \mathrm{NO}_{3}^{-}, \mathrm{Cl}^{-}, \mathrm{Br}^{-}, \mathrm{CH}_{3} \mathrm{COO}^{-}\right.$and $\left.\mathrm{SCN}^{-}\right)$. Although EMF of the $\mathrm{Co}_{58} \mathrm{Fe}_{42}$ thin-film electrode responded to some anions within $\pm 15 \mathrm{mV}$, this sensor showed excellent selectivity to $\mathrm{H}_{2} \mathrm{PO}_{4}^{-}$.

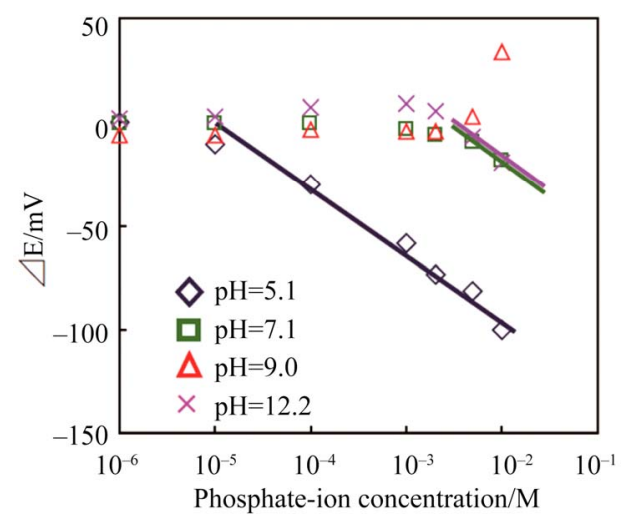

Figure 5. Sensing performance of the $\mathrm{Co}_{58} \mathrm{Fe}_{42}$ thin-film electrode to phosphate ion $\left(\mathrm{H}_{2} \mathrm{PO}_{4}^{-}, \mathrm{HPO}_{4}^{2-}\right.$ and $\mathrm{PO}_{4}^{3-}$ at various $\mathrm{pH}$ values) at $30^{\circ} \mathrm{C}$.

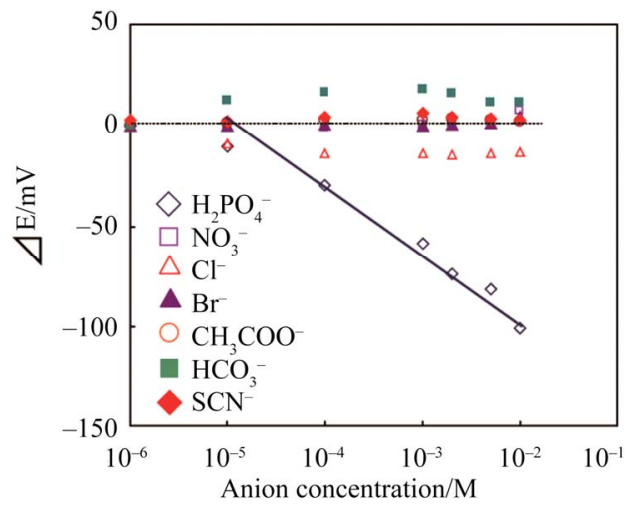

Figure 6. EMF responses of the $\mathrm{Co}_{58} \mathrm{Fe}_{42}$ thin-film electrode to various anions.

\subsection{Sensing Mechanism of the Co-Fe Metal Thin-Film Electrode}

X-ray photoelectron (XPS) spectra $[4,18,22]$ of the surfaces of the $\mathrm{Co}$ and $\mathrm{Co}_{58} \mathrm{Fe}_{42}$ thin-film electrodes before and after measurement to $\mathrm{H}_{2} \mathrm{PO}_{4}^{-}$were investigated. Figure 7(a) shows Co $2 p$ peaks of the Co-only thin-film electrode before and after measurements. $\mathrm{Co}_{2 \mathrm{p} 3 / 2}$ peaks appeared at $780.0 \mathrm{eV}$ and $781.3 \mathrm{eV}$, and $\mathrm{Co}_{2 \mathrm{p} 1 / 2}$ peaks appeared at $796.4 \mathrm{eV}$ and $797.1 \mathrm{eV}$, indicating that the surface of the Co thin-film was in both states of $\mathrm{Co}^{2+}$ and $\mathrm{Co}^{3+}$ before and after measurements. Figure 7(b) shows Co $2 \mathrm{p}$ peaks of the $\mathrm{Co}_{58} \mathrm{Fe}_{42}$ thin-film electrode before and after measurements, indicating that the $\mathrm{Co}_{2 \mathrm{p} 3 / 2}$ peaks for the surface of the $\mathrm{Co}_{58} \mathrm{Fe}_{42}$ thin-film existed in both states of $\mathrm{Co}^{2+}$ and $\mathrm{Co}^{3+}$ before and after measurements. It can also be seen that the $\mathrm{Co}_{58} \mathrm{Fe}_{42}$ thin-film electrode before the measurement included a richer state of $\mathrm{Co}^{2+}$ than that of $\mathrm{Co}^{3+}$. It is thought that $\mathrm{Fe}$ in the $\mathrm{Co}-\mathrm{Fe}$ alloy reduces the state of $\mathrm{Co}$ from $\mathrm{Co}^{3+}$ to $\mathrm{Co}^{2+}$,

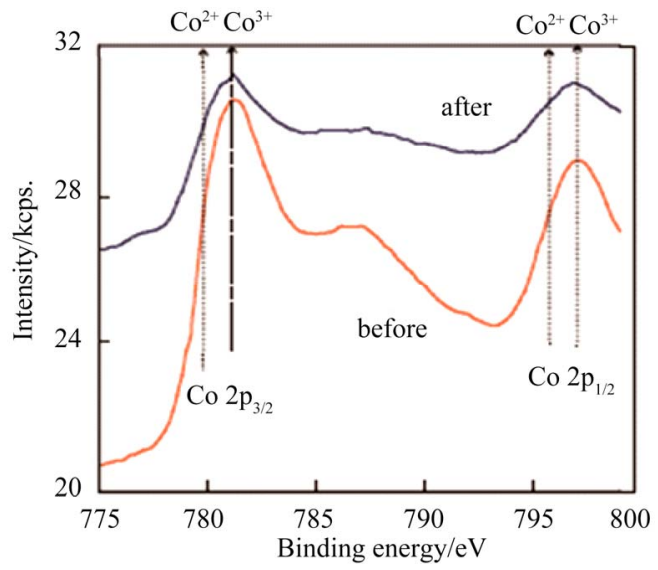

(a)

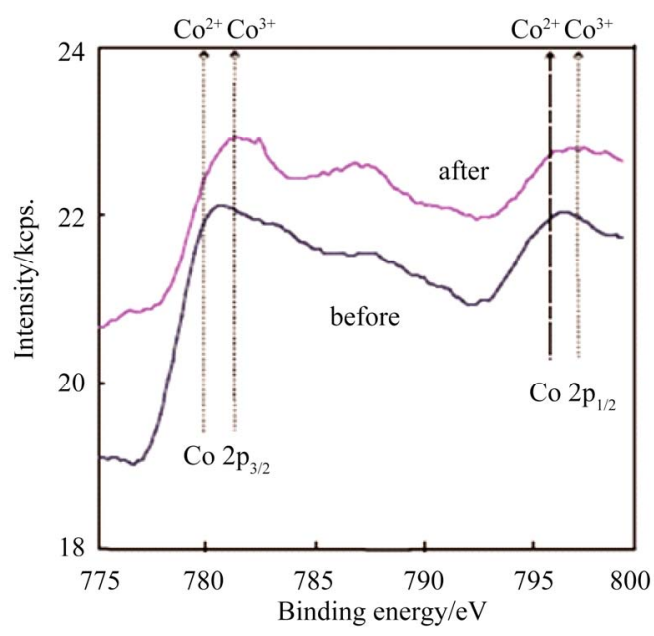

(b)

Figure 7. XPS spectra of cobalt on the surfaces of (a) Co and (b) $\mathrm{Co}_{58} \mathrm{Fe}_{42}$ thin-film electrodes before and after measurements for hydrogen-phosphate ion sensing. 
and then the $\mathrm{Co}^{2+}$ state in the Co-Fe alloy was more stabilized than that in the Co-only electrode. It was also revealed that the state of $\mathrm{Co}^{3+}$ after sensor measurements was richer than that of $\mathrm{Co}^{2+}$ in the $\mathrm{Co}_{58} \mathrm{Fe}_{42}$ thin-film, although they also showed both $\mathrm{Co}^{2+}$ and $\mathrm{Co}^{3+}$ states. Figure 8 shows Fe 2 p peaks of the $\mathrm{Co}_{58} \mathrm{Fe}_{42}$ electrode before and after measurements. $\mathrm{Fe}_{2 \mathrm{p} 3 / 2}$ peaks before the measurement appeared at $709.4 \mathrm{eV}$ and $711.4 \mathrm{eV}$, indicating the presence of both states of $\mathrm{Fe}^{2+}$ and $\mathrm{Fe}^{3+}$ on the surface of the film. After the sensor measurement, the peak at $709 \mathrm{eV}$ decreased and mainly consists of the peak at $711.6 \mathrm{eV}$ of $\mathrm{Fe}^{3+}$. Thus, it turned out that the surface of the $\mathrm{Co}_{58} \mathrm{Fe}_{42}$ thin-film electrode was in the state of coexistence of $\mathrm{Fe}^{2+}$ and $\mathrm{Fe}^{3+}$ before the measurement, and it changed to a richer state of $\mathrm{Fe}^{3+}$ than that of $\mathrm{Fe}^{2+}$ after exposure to the electrolyte.

FT-IR spectra of the $\mathrm{CO}_{58} \mathrm{Fe}_{42}$ thin-film electrode before and after $\mathrm{H}_{2} \mathrm{PO}_{4}^{-}$measurements are shown in Figure 9. Absorptions of $v(\mathrm{Co}-\mathrm{O})$ and $v(\mathrm{Fe}-\mathrm{O})$ at around 484 and $791 \mathrm{~cm}^{-1}$, respectively, appeared before the measurement [23,24]. Absorptions at around 1030, 1100 and $1600 \mathrm{~cm}^{-1}$ should be indicated for $v\left(\mathrm{BO}_{3}^{3-}\right), v\left(\mathrm{SO}_{4}^{2-}\right)$ and $v\left(\mathrm{OH}^{-}\right)$from the electrolyte, respectively. Large absorption at $1360 \mathrm{~cm}^{-1}$ for $v(\mathrm{MOOH})$ should be come from $\mathrm{FeOOH}$, as also observed in Figure 1.

After the sensor measurement, broad absorptions of $v(\mathrm{Co}-\mathrm{O})$ appeared at around 482 and $553 \mathrm{~cm}^{-1}$. Absorption of $v(\mathrm{Fe}-\mathrm{O})$ also appeared at 752 and $810 \mathrm{~cm}^{-1}$. The $\mathrm{M}-\mathrm{O}(\mathrm{M}=\mathrm{Co}, \mathrm{Fe})$ band shifted to a higher wave number, indicating that lower-valence metal ions $\left(\mathrm{Co}^{2+}, \mathrm{Fe}^{2+}\right)$ are oxidized to higher-valence metal ions $\left(\mathrm{Co}^{3+}, \mathrm{Fe}^{3+}\right)$, as also shown by the XPS results.

Moreover, absorption of $v\left(\mathrm{H}_{2} \mathrm{PO}_{4}^{-}\right)$newly appeared at $1040 \mathrm{~cm}^{-1}$ [24]. The Co-site seems to be more sensitive

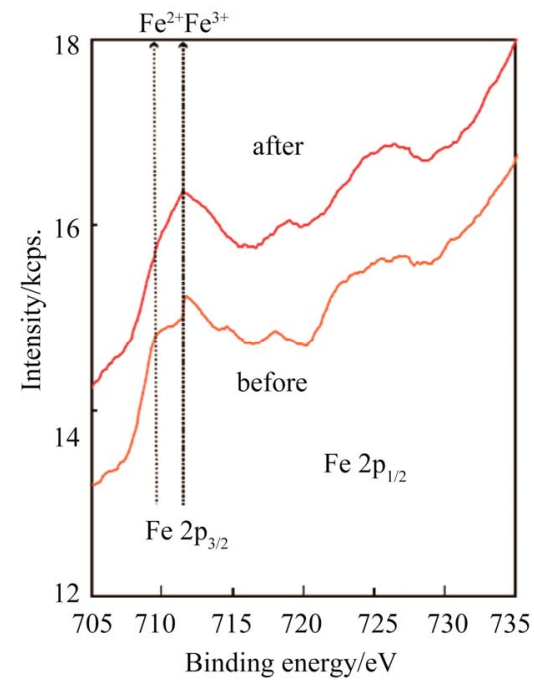

Figure 8. XPS spectra of iron on the surface of the $\mathrm{Co}_{58} \mathrm{Fe}_{42}$ thin-film electrode before and after measurements for hydrogen-phosphate ion sensing. to hydrogen-phosphate ion than that of $\mathrm{Fe}$ in the Co-Fe alloy, and the sensitivity to $\mathrm{H}_{2} \mathrm{PO}_{4}^{-}$was thus decreased at the highest $\mathrm{Fe}$ content in the Co-Fe alloy, as shown in Table 1. When the XPS and FT-IR spectra were taken into consideration, the surface of the $\mathrm{Co}-\mathrm{Fe}$ electrode before measurement formed $\mathrm{Co}_{3} \mathrm{O}_{4}(\mathrm{Co}(\mathrm{II}), \mathrm{Co}(\mathrm{III}))$ and $\mathrm{Fe}_{3} \mathrm{O}_{4}(\mathrm{Fe}$ (II), $\mathrm{Fe}(\mathrm{III}))$ and changed after measurement to $\mathrm{Co}\left(\mathrm{H}_{2} \mathrm{PO}_{4}\right)_{3}(\mathrm{Co}(\mathrm{III}))$ and $\mathrm{Fe}\left(\mathrm{H}_{2} \mathrm{PO}_{4}\right)_{3}(\mathrm{Fe}(\mathrm{III}))($ or $\mathrm{FeOOH})$, respectively.

The slope of the line for EMF versus $\log \left[\mathrm{H}_{2} \mathrm{PO}_{4}^{-}\right]$ was largely dependent on the electrode materials. Thus, the sensing mechanism seems arise not from the conventional Nernst' type but probably the mixed potential one, as already reported $[3,18]$. When the sensing electrode is exposed to $\mathrm{H}_{2} \mathrm{PO}_{4}^{-}$ion including dissolved oxygen, electrochemical reduction (1) and electrochemical $\mathrm{H}_{2} \mathrm{PO}_{4}^{-}$ oxidation (2), (2') take place simultaneously.

$$
\begin{gathered}
\mathrm{O}_{2}+4 \mathrm{H}^{+}+4 \mathrm{e}^{-} \rightarrow 2 \mathrm{H}_{2} \mathrm{O} \\
\mathrm{Co}_{3} \mathrm{O}_{4}+9 \mathrm{H}_{2} \mathrm{PO}_{4}^{-}+8 \mathrm{H}^{+} \rightarrow 3 \mathrm{Co}\left(\mathrm{H}_{2} \mathrm{PO}_{4}\right)_{3}+4 \mathrm{H}_{2} \mathrm{O}+\mathrm{e}^{-} \\
\mathrm{CoO}+3 \mathrm{H}_{2} \mathrm{PO}_{4}^{-}+2 \mathrm{H}^{+} \rightarrow \mathrm{Co}\left(\mathrm{H}_{2} \mathrm{PO}_{4}\right)_{3}+\mathrm{H}_{2} \mathrm{O}+\mathrm{e}^{-}
\end{gathered}
$$

The two cathodic and anodic electrochemical reactions form a local cell and determine the mixed electrode potential. Figure 10 shows schematic polarization curves for both the anodic and cathodic reactions. As a sensor device, the sensing signal of the Co-Fe electrode should be a more accurate value than the Co-only one, that is, the slope of EMF versus $\log \left[\mathrm{H}_{2} \mathrm{PO}_{4}^{-}\right]$should be larger. When we consider cases (C-I) and (C-II) for cathodic reaction as shown in Figure 10, the mixed potentials gave a larger slope in the order of $(\mathrm{C}-\mathrm{I})>(\mathrm{C}-\mathrm{II})$. The value of the slope $\mathrm{E}$ versus $\log \mathrm{I}$ at the small current area

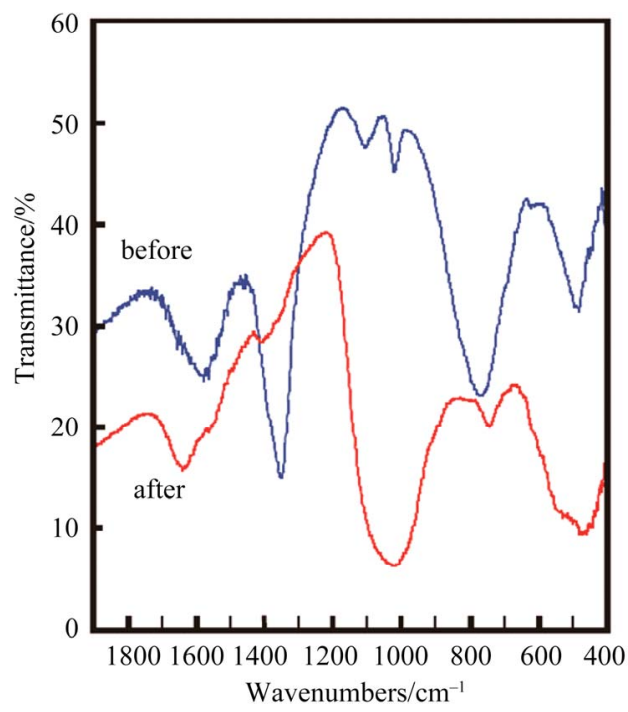

Figure 9. FT-IR spectra of the $\mathrm{Co}_{58} \mathrm{Fe}_{42}$ thin-film electrode before and after measurements for hydrogen-phosphate ion sensing. 


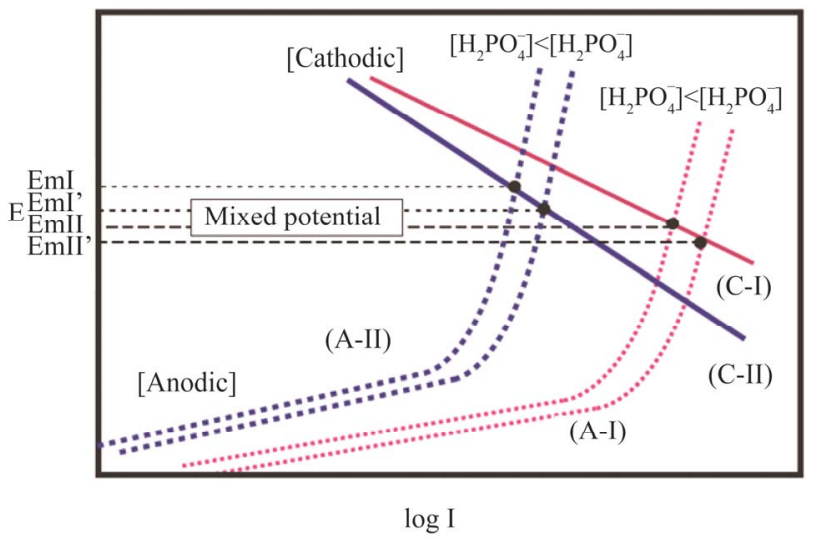

Figure 10. Schematic polarization curves for cathodic and anodic electrochemical reactions of the sensor electrode.

means a Tafel slope of the anodic reaction (1), which shows electrocatalytic activity to reaction (1). Since the electro chemical cathodic activity is in the order of (C-I) $>$ (C-II) electrocatalytic oxygen reduction activities should be in the order of Co-only and Co-Fe alloy electrodes. It should be considered that the mixed potential is to be sifted anodically, if the anodic electrochemical reaction activity was low due to electrocatalytic activities. When the electrochemical oxidation activity was in the order of $(\mathrm{A}-\mathrm{I})>(\mathrm{A}-\mathrm{II})$, the mixed potential showed more anodic potentials, as shown in Figure 10. For this reason, the Co-Fe alloy electrode showed more positive electrode potential and a large slope in EMF versus $\log \left[\mathrm{H}_{2} \mathrm{PO}_{4}^{-}\right]$ plots compared to those of the Co-only electrode.

It is thought that anodic reaction between Co-based electrode and $\mathrm{H}_{2} \mathrm{PO}_{4}^{-}$tends to take place more easily on a $\mathrm{Co}$ (II)-rich surface as like $\mathrm{CoO}$. The $\mathrm{Co}$ (II)-rich surface should be stabilized by Fe in the alloy by chemical reaction (3). Reaction (3) should consist of (3-1) and (3-2).

$$
\begin{gathered}
2 \mathrm{Fe}_{3} \mathrm{O}_{4}+\mathrm{Co}_{3} \mathrm{O}_{4}+3 \mathrm{H}_{2} \mathrm{O} \rightarrow 6 \mathrm{FeOOH}+3 \mathrm{CoO} \\
2 \mathrm{Fe}_{3} \mathrm{O}_{4}+4 \mathrm{H}_{2} \mathrm{O} \rightarrow 6 \mathrm{FeOOH}+2 \mathrm{H}^{+}+2 \mathrm{e}^{-} \\
\mathrm{Co}_{3} \mathrm{O}_{4}+2 \mathrm{H}^{+}+2 \mathrm{e}^{-} \rightarrow 3 \mathrm{CoO}
\end{gathered}
$$

Thus, the Co-Fe alloy electrode should show quick response and long-term stability. However, further investigations are needed to determine the sensing mechanisms of the present electrochemical device.

\section{Conclusion}

Potentiometric hydrogen-phosphate ion-sensing characteristics of various Co-based alloy electrodes were investigated. Among the alloys tested, the $\mathrm{Co}_{58} \mathrm{Fe}_{42}$ thin-film electrode showed good hydrogen-phosphate ion-sensing characteristics of fast response rate, high selectivity, and high reproducibility. Electrochemical reactions for the mixed potential mechanism of the Co-based potentiometric sensor were proposed from XRD, XPS and FT-IR measurements. Further development of materials of the metal-alloy system should improve the sensor performance.

\section{Acknowledgements}

The authors are grateful to the Center for Instrumental Analysis, Kyushu Institute of Technology for XRD, SEM and FT-IR measurements.

\section{REFERENCES}

[1] G. G. Guilbault and P. J. Bringnac Jr., "Study of Various Inorganic Phosphate Salts Impregnated in Silicone Rubber as Potential Indicating Electrodes for Phosphate Ion," Analytical Chemistry, Vol. 41, No. 8, 1969, pp. 1136-1138. doi:10.1021/ac60277a027

[2] G. S. Ihn, C. F. Nash and R. P. Buck, "Monohydrogenphosphate-Sensitive Electrode Formulations," Analytica Chimica Acta, Vol. 121, 1980, pp. 101-109. doi:10.1016/S0003-2670(01)84404-4

[3] R. K. Meruva and M. E. Meyerhoff, "Mixed Potential Response Mechanism of Cobalt Electrodes toward Inorganic Phosphate," Analytical Chemistry, Vol. 68, No. 13, 1996, pp. 2022-2026. doi:10.1021/ac951086v

[4] D. Xiao, H.-Y. Yuan, J. Li and R. Q. Yu, "Surface-Modified Cobalt-Based Sensor as a Phosphate-Sensitive Electrode," Analytical Chemistry, Vol. 67, No. 2, 1995, pp. 288-291. doi:10.1021/ac00098a009

[5] N. Sato and Y. Fukuda, "Anion-Sensing Electrodes Based on Nikel(II) and Copper(II) Mixed Ligand Complexes," Sensors and Actuators B: Chemical, Vol. 14, No. 1-3, 1993, pp. 743-745. doi:10.1016/0925-4005(93)85167-9

[6] S. A. Glazier and M. A. Arnold, "Selectivity of Membrane Electrodes Based on Derivatives of Dibenzyltin Dichloride," Analytical Chemistry, Vol. 63, No. 8, 1991, pp. 754-759. doi:10.1021/ac00008a003

[7] J. Liu, Y. Masuda, E. Sekido, S. Wakida and K. Hiiro, "Phosphate Ion-Selective Coated-Wire/Field-Effect Transistor Electrode Based on Cobalt Phthalocyanine with Poly(Vinyl Chloride) as the Membrane Matrix," Analytica Chimica Acta, Vol. 224, 1989, pp. 145-151. doi:10.1016/S0003-2670(00)83455-8

[8] M. Suzuki, H. Kurata, Y. Inoue, H. Shin, I. Kubo, H. Nakomura, K. Ikebukuro and I. Karube, "Reagentless Phosphate Ion Sensor System for Envieonmental Monitoring," Electrochemistry, Vol. 66, No. 6, 1998, pp. 579-583.

[9] G. C. Petrucelli, E. Y. Kawachi, L. T. Kubota and C. A. Bertran, "Hydroxyapatite-Based Electrode: A New Sensor for Phosphate," Analytical Communications, Vol. 33, No. 7, 1996, pp. 227-229. doi:10.1039/ac9963300227

[10] Y. Shimizu and Y. Furuta, "An Opto-Electrochemical Phosphate-Ion Sensor Using a Cobalt-Oxide Thin-Film Electrode," Solid State Ionics, Vol. 113-115, 1998, pp. 241-245. doi:10.1016/S0167-2738(98)00288-4

[11] Y. Shimizu, T. Yamashita and S. Takase, "Electrochro- 
mic Phosphate-Ion Sensor Based on Nickel-Oxide ThinFilm Electrode," Japanese Journal of Applied Physics, Part 2, Vol. 39, 2000, pp. L384-L386. doi:10.1143/JJAP.39.L384

[12] Y. Shimizu, A. Ishikawa, K. Iseki and S. Takase, "Perovskite-Type Oxide Based Electrode: A New Sensor for Hydrogen-Phosphate Ion," Journal of the Electrochemical Society, Vol. 147, No. 10, 2000, pp. 3931-3934. doi:10.1149/1.1393998

[13] S. Takase, S. Matsumoto and Y. Shimizu, "Preparation of Amperometric Hydrogen-Phosphate Ion Sensor Based on Perovskite-Type Oxide Thick-Film by EPD Process," Electrochemistry, Vol. 78, No. 2, 2010, pp. 150-152.

[14] M. R. Ganjali, P. Norouzi, M. Ghomi and M. SalavatiNiasari, "Highly Selective and Sensitive Monohydrogen Phosphate Membrane Sensor Based on Molybdenum Acetylacetonate," Analytica Chimica Acta, Vol. 567, No. 2, 2006, pp. 196-201. doi:10.1016/j.aca.2006.03.026

[15] T. L. Goff, J. Braven, L. Ebdon and D. Scholefield, "Phosphate-Selective Electrodes Containing Immobilised Ionophores," Analytica Chimica Acta, Vol. 510, No. 2, 2004, pp. 175-182. doi:10.1016/j.aca.2004.01.015

[16] Z. Chen, P. Grierson and M. A. Adams, "Direct Determination of Phosphate in Soil Extracts by Potentiometric Flow Injection Using a Cobalt Wire Electrode," Analytica Chimica Acta, Vol. 363, No. 2, 1998, pp. 191-197. doi:10.1016/S0003-2670(98)00137-8

[17] S. O. Engblom, "The Phosphate Sensor," Biosensors and Bioelectronics, Vol. 13, No. 9, 1998, pp. 981-994. doi:10.1016/S0956-5663(98)00001-3

[18] R. D. Marco, B. Peject and Z. Chen, "Flow Injection Potentiometric Determination of Phosphate in Waste and
Fertilisers Using a Cobalt Wire Ion-Selective Electrode," Analyst, Vol. 123, No. 7, 1998, pp. 1635-1640. doi:10.1039/a801244j

[19] Z. Zou, J. Han, A. J. Paul, L. Bishop and C. H. Ahn, “A Disposable On-Chip Phosphate Sensor with Planar Cobalt Microelectrodes on Polymer Substrate," Biosensors and Bioelectronics, Vol. 22, No. 9-10, 2007, pp. 1902-1907. doi:10.1016/j.bios.2006.08.004

[20] C. W. Tang, C. B. Wang and S. H. Chien, "Characterization of Cobalt Oxides Studied by FT-IR, Raman, TPR and TG-MS," Thermochimica Acta, Vol. 473, No. 1-2, 2008, pp. 68-73. doi:10.1016/j.tca.2008.04.015

[21] K. Hong, J. Lee, J. Lee, Y.-D. Ko, J.-S. Chung and J.-G. $\mathrm{Kim}$, "Property Changes of Electroplated $\mathrm{Cu} / \mathrm{Co}$ Alloys and Multilayers by Organic Additives," Journal of Magnetism and Magnetic Materials, Vol. 304, No. 1, 2006, pp. 60-63. doi:10.1016/j.jmmm.2006.02.008

[22] C. D. Wagner, W. M. Riggs, L. E. Davis, J. F. Moulder and G. E. Muilenberg, "Handbook of X-Ray Photoelectron Spectroscopy," Perkin-Elmer, Co., Minnesota, 1979.

[23] M. E. Baydi, S. K. Tiwari, R. N. Singh, J.-L. Rehspringer, P. Chartier, J. F. Koening and G. Poillerat, "High Specific Surface Area Nickel Mixed Oxide Powders $\mathrm{LaNiO}_{3}(\mathrm{Pe}-$ rovskite) and $\mathrm{NiCo}_{2} \mathrm{O}_{4}$ (Spinel) via Sol-Gel Type Routes for Oxygen Electrocatalysis in Alkaline Media," Journal of Solid State Chemisty, Vol. 116, No. 1, 1995, pp. 157169. doi:10.1006/jssc. 1995.1197

[24] K. Nakamoto, "Infrared and Raman Spectra of Inorganic and Coordination Compounds," 5th Edition, Wiley-Interscience, New York, 1997. 